Original article

\title{
Antidepressant and antinociceptive activities in animal models and in vitro assessment of the anti-thyroid activity of bis(DL-pyroglutamate) magnesium complex
}

\author{
Nancy Martini ${ }^{\mathrm{a}, \mathrm{d}}$, Juliana E. Parente ${ }^{\mathrm{a}, \mathrm{d}}$, Maria Eugenia Toledo ${ }^{\mathrm{b}, \mathrm{d}}$, Graciela E. Escudero, ${ }^{\mathrm{c}, \mathrm{d}}$, \\ Carlos H. Laino ${ }^{\mathrm{b}, \mathrm{d}}$, Oscar E. Piro ${ }^{\mathrm{c}, \mathrm{d}}$, Gustavo A. Echeverría ${ }^{\mathrm{c}, \mathrm{d}}$, Patricia A.M. Williams ${ }^{\mathrm{a}, \mathrm{d}}$, \\ Evelina G. Ferrer ${ }^{a, d, *}$ \\ a Centro de Química Inorgánica (CEQUINOR-CONICET-CICPBA-UNLP)-Departamento de Química - Facultad de Ciencias Exactas, Universidad Nacional de La
Plata, La Plata, Argentina
b Instituto de Biotecnología del CENIIT-UNLaR (Centro de Investigación e Innovación Tecnológica), La Rioja, Argentina
${ }^{\mathrm{c}}$ Instituto de Bioquímica y Farmacia del CENIIT-UNLaR (Centro de Investigación e Innovación Tecnológica), La Rioja, Argentina
${ }^{\mathrm{d}}$ Departamento de Física, Facultad de Ciencias Exactas, Universidad Nacional de La Plata and IFLP (CONICET, CCT-La Plata), La Plata, Argentina
}

A R T I C L E I N F O

\section{Article history:}

Received 15 March 2019

Received in revised form 18 June 2019

Accepted 25 July 2019

Available online 5 August 2019

\section{Keywords:}

DL-pyroglutamic acid

Magnesium

Antidepressant activity

Anti-thyroid activity

Antinociceptive activity

\begin{abstract}
A B S T R A C T
Background: Magnesium is an essential element related with biochemistry of the brain and different types of depression have been associated with its deficiency.

Methods: The structure of a novel magnesium bis(DL-pyroglutamate) (Mg(DL-pGlu $\left.)_{2}\right)$ was elucidated by $\mathrm{X}$-ray crystallography. Wistar rats were used in the in vivo experiments. The antidepressant-like effect was assessed by the forced swim test (FST) and the antinociceptive activity was evaluated using hot plate test. In both, non-specific effects were evaluated by the open field test. Anti-thyroid activity was examined using Lang's method. Albumin binding behavior was evaluated by 3D fluorescence spectroscopy.

Results: For the $\mathrm{Mg}(\mathrm{DL}-\mathrm{pGlu})_{2}$ complex (30 mg/kg), the FST test on Wistar rats revealed a decrease of $22 \%$ in the immobility time and an increment of $106 \%$ in the swimming time. The compound alters neither the locomotor activity nor the body weight after chronic administration. At the same dose, it showed antinociceptive activity, increasing the response latency. It blocks iodination reactions generating a charge transfer complex with iodine hence indicating anti-thyroid activity $\left(\mathrm{K}_{\mathrm{c}}=45366.5 \pm 29 \mathrm{M}^{-1}\right)$. Albumin 3D fluorescence spectroscopy experiments showed intensity increase of peak A and decrease of peak B.

Conclusions: The results showed that the new compound produced a lowering of the immobility time and an increment of the swimming ability of the rats. The compound is able to increase the response latency in $70.0 \%$, to capture iodine (anti-thyroid activity) and to interact with albumin through covalent type of interaction of the free $\mathrm{NH}$ groups.
\end{abstract}

(C) 2019 Maj Institute of Pharmacology, Polish Academy of Sciences. Published by Elsevier B.V. All rights

reserved.

\section{Introduction}

Magnesium is an essential element and one of the main intracellular earth-metal cation with a cytosolic concentration of about $0.5 \mathrm{mM}$ being the second most abundant cation. $\mathrm{Mg}$ (II) acts as a cofactor of several enzymatic reactions [1,2] and its insufficiency were described for various pathological conditions

\footnotetext{
* Corresponding author.

E-mail address: evelina@quimica.unlp.edu.ar (E.G. Ferrer).
}

in humans. Magnesium compounds began to be prescribed as a supplement and there are many formulations for (i) prophylaxis [3], (ii) electrolyte balance restoration [4], (iii) improving nutrition, cognitive [5], (iv) Alzheimer's disease, attention deficit hyperactivity disorder, Parkinson's disease, anxiety disorder, etc [6], (v) pain [7], (vi) stimulating epidermal renewal [8]. In addition, pyroglutamic acid and their metal derivatives (pidolates) have long been used as supplementation drugs [9,10] and cosmetics [11].

Depression is a mental disorder characterized by persistent sadness, loss of interest, loss of energy, appetite change, anxiety, feelings of worthlessness, etc. (WHO 2017) [12]. Depression, 
anxiety and apathy have been related with magnesium insufficiency [13]. Preclinical and clinical reports support therapeutic application of magnesium compounds [14]. Magnesium has also been associated with the lowering of pain. Patients with chronic fatigue treated with magnesium improved energy levels, emotional state and suffered less pain [14]. Patients with depression and chronic pain showed magnesium deficiency and those having chronic stress (including pain) increased the requirement of magnesium administration [15].

There seems to be a link between depressive disorder and hyperthyroidism disease. Studies showed that depression aggravates the prognosis of antithyroid drug-treated hyper-thyroidism [16] and restores the levels of circulating thyroxine after treatment [17]. Clinical studies on thyroxicosis linked magnesium deficiency with hyperthyroidism [18]. It is known that some antidepressants may act as anti-thyroid drugs [19] and that there is of pharmacological interest to investigate drugs in tablets and ophthalmic solutions [20]. The above information prompted us to study the anti-thyroid activity of the new compound.

The binding ability of the magnesium complex to albumin was also assessed considering the extraordinary ligand carrier capacity of this protein as main modulator of fluid distribution in the body [21].

\section{Materials and methods}

All chemicals including solvents were of analytical grade: $\mathrm{Mg}\left(\mathrm{NO}_{3}\right)_{2} \cdot 6 \mathrm{H}_{2} \mathrm{O}$ and $\mathrm{MgCl}_{2} \cdot 6 \mathrm{H}_{2} \mathrm{O}$ (Biopack), DL-pyroglutamic acid (MP Biomedicals), iodine (Merck). Albumin and all the other analytical grade chemicals used were purchased from Sigma. Elemental analyses were performed using a Carlo Erba EA 1108 analyzer. Equipment related to thermo-gravimetric analysis, FTIR, Raman, UV-vis and fluorescence spectroscopies have been described in reference [22].

\section{Synthesis of $\left[\mathrm{Mg}(\mathrm{DL}-\mathrm{pGlu})_{2}\right]$}

Solvothermal reaction of $1 \mathrm{mmol}$ of $\mathrm{Mg}\left(\mathrm{NO}_{3}\right)_{2} \cdot 6 \mathrm{H}_{2} \mathrm{O}$ and $1 \mathrm{mmol}$ of DL-pyroglutamic acid (DL-pGlu acid) in $3.5 \mathrm{~mL}$ of $\mathrm{N}$, $\mathrm{N}$-dimethylacetamide solvent at $100{ }^{\circ} \mathrm{C}$ for 5 days produced single crystals suitable for structural X-ray diffraction. Crystals were filtered out, washed with $\mathrm{N}, \mathrm{N}$-dimethylacetamide and air dried. This reaction was also carried out under the same experimental conditions but with higher concentrations of the compounds to obtain a microcrystalline powder. This solid produced an X-ray diffraction pattern which is coincident with the one calculated from the single crystal X-ray structure (see supplementary information for single crystal data, structure solution, refinement, FTIR, UV-vis and conductivity). Elemental analyses for $\mathrm{C}, \mathrm{H}, \mathrm{N}$ confirm the composition: $\mathrm{C}_{10} \mathrm{H}_{12} \mathrm{MgN}_{2} \mathrm{O}_{6}$ : Calculated: $42.8 \% \mathrm{C}, 4.3 \%$ $\mathrm{H} ; 10 \% \mathrm{~N}$. Found: $42.5 \% \mathrm{C}, 4.1 \% \mathrm{H}, 9.8 \% \mathrm{~N}$.

\section{In vitro biological and pharmacological activities}

\section{Anti-thyroid activity}

Iodine complexation was assayed based on Lang's method [23] Iodine was bi-sublimated and kept in dark in a desiccator containing $\mathrm{P}_{2} \mathrm{O}_{5}$. Spectroscopic grade solvent were used. Solutions of iodine, DL-pGlu acid and $\mathrm{Mg}(\mathrm{DL}-\mathrm{pGlu})_{2}$ were prepared just before the beginning of experimentation. Iodine concentration was kept constant (ethanol, $2 \times 10^{-4} \mathrm{M}$ ), and the concentrations of the ligand and the complex were varied between $1 \times 10^{-4}$ and $1 \times 10^{-3}$ $\mathrm{M}$ (DMF- $\mathrm{H}_{2} \mathrm{O}$ 10:1). The reaction was carried out directly in the spectrophotometric cell by mixing $1.5 \mathrm{~mL}$ solutions of the donors and the acceptor (iodine). Spectra were recorded immediately on a double beam UV-vis spectrophotometer. The temperature of the solutions was kept at $25 \pm 1{ }^{\circ} \mathrm{C}$ during the measurements. Three independent replicates of each solution were measured. The formation constant $\left(\mathrm{K}_{\mathrm{c}}\right)$ and the molar extinction coefficient were determined. This method has been used to determine the formation constants of $1: 1$ stoichiometric complexes at the wavelength under analysis using:

$\left[\mathrm{A}_{0}\right]\left[\mathrm{D}_{0}\right] / \mathrm{d}_{\mathrm{c}}=\left(\left[\mathrm{A}_{0}\right]+\left[\mathrm{D}_{0}\right]-\mathrm{d}_{\mathrm{c}} / \varepsilon_{\mathrm{c}}\right) / \varepsilon_{\mathrm{c}}+1 / \mathrm{K}_{\mathrm{c}} \varepsilon_{\mathrm{c}}$

In Eq. (1), $d_{c}$ is the absorbance, $\varepsilon_{c}$ is the molar extinction coefficient and $\mathrm{K}_{\mathrm{c}}$ is the formation constant of the CT-complex. Parameters were adjusted using a program designed by our research group.

Eq. (1) can be re-written in the form:

$\mathrm{Y}=\left(1 / \varepsilon_{\mathrm{c}}\right) \mathrm{X}+1 / \mathrm{K}_{\mathrm{c}} \varepsilon_{\mathrm{c}}$

where $Y=\left[A_{0}\right]\left[D_{0}\right] / d_{c}$ and $X=\left[A_{0}\right]+\left[D_{0}\right]-d_{c} / \varepsilon_{c}$.

and a straight line with slope $1 / \varepsilon_{\mathrm{c}}$ and Y-intercept $1 /\left(\mathrm{K}_{\mathrm{c}} \varepsilon_{\mathrm{c}}\right)$ has been obtained.

Iteration and linear regression methods were used to solve Eq. (2). A suggested initial value of $\varepsilon_{\mathrm{c}}$ was dispensed and an X value was calculated. From the slope of the line, a new $\varepsilon_{\mathrm{c}}$ was determined and the process was iterated several times until convergence of $\varepsilon_{c}$ and $\mathrm{K}_{\mathrm{c}}$ values.

In addition, the free energy change $\Delta G^{0}$ was calculated from Gibbs free energy of formation according to the equation: $\Delta G^{0}=-R T \ln K_{c}$, where $\Delta G^{0}$ is the free energy change of the CTcomplex, $\mathrm{R}$ is the gas constant $(8.31 \mathrm{~J} / \mathrm{Kmol}), \mathrm{T}$ is the temperature in Kelvin and $\mathrm{K}_{\mathrm{c}}$ is the formation constant of donor-acceptor complex.

Experiments concerning lactoperoxidase from bovine milk (LPO)-inhibition were performed using phosphate buffer $(\mathrm{pH} 7)$ at $25{ }^{\circ} \mathrm{C}$ according to Roy et al. procedure [24]. In this study, we employed the Fe-containing LPO as a model for TPO, because both of the enzymes have shown similar properties. The LPO enzyme activity was followed by catalysis of ABTS oxidation monitoring the UV absorption at $411 \mathrm{~nm}$. The enzyme activity, upon complex addition, was expressed as a percentage of the activity in the absence of inhibitors (control). In the experiment, solutions of $100 \mathrm{mM}$ ABTS and $30 \mathrm{mM}$ hydrogen peroxide solutions were freshly prepared in deionized water. Lactoperoxidase enzyme (0.15-0.25 unit $\mathrm{mL}^{-1}$ ) was prepared in cold deionized water and used immediately. In a $1 \mathrm{~mL}$ reaction mixture, concentrations of $12.9 \mathrm{nM} \mathrm{LPO}, 28.7 \mathrm{mM} \mathrm{H}_{2} \mathrm{O}_{2}, 1.4 \mathrm{mM}$ ABTS, and $1-500 \mu \mathrm{M}$ of the inhibitor were fixed in the final solution.

In vivo pharmacologic screening

\section{Animals}

Experiments were carried out on male Wistar rats weighing $170-290 \mathrm{~g}$. The animals were housed in groups of 4- rats/ polyethylene cages $(55 \times 38 \times 30 \mathrm{~cm})$ at ambient room temperature of $22 \pm 2{ }^{\circ} \mathrm{C}$ and relative humidity of $50 \pm 5 \%$ and maintained under a 12:12 h dark light cycle (lights on at 08:00 h). Food and water were available ad libitum except during specific experimental protocol [22]. Rats were used only for one type of experiment. Their weights were recorded at the beginning and end of each experiment. Ambient temperature of the room and humidity were maintained consistent in all the tests.

All studies described were conducted in accordance with the Guide for Care and Use of Laboratory Animals provided by the National Institutes of Health, USA and AVMA Guidelines for the Euthanasia of Animals, 2013 Ed. The experiments were performed after approval of the protocol by the Ethics Committee for the care and use of Laboratory Animals of the Universidad Nacional de La Rioja, Argentina (SNB Res. $\mathrm{N}^{0} 072 / 15$ ). 


\section{Antidepressant activity}

\section{Drugs and treatment}

Based on previous researches, the doses of 20 and $30 \mathrm{mg}$ $(\mathrm{Mg}) / \mathrm{kg}$ were chosen as starting doses in the experiments [25]. The doses of the magnesium compound were calculated as the quantity of magnesium element. Doses of DL-pGlu are calculated as amounts corresponding to those present in $[\mathrm{Mg}(\mathrm{DL}-$ pGlu $)_{2}$ ]. Rats were treated with the saline solution (sal, rats control) or DL-pGlu acid, $\mathrm{MgCl}_{2}$ and $\left[\mathrm{Mg}(\mathrm{DL}-\mathrm{pGlu})_{2}\right.$ ] once a day and all solutions were administered by oral route in a constant volume of $10 \mathrm{ml} / \mathrm{kg}$ body weight. The rats were randomly distributed into seven groups which were subjected to the following treatments: Group 1: saline (control group), Group 2: $\mathrm{MgCl}_{2}$ (60 mg, $20 \mathrm{mg}(\mathrm{Mg}) / \mathrm{kg}$ ), Group 3: $\mathrm{MgCl}_{2}(87.5 \mathrm{mg}, 30 \mathrm{mg}$ $(\mathrm{Mg}) / \mathrm{kg})$, Group 4. DL-pGlu acid $(73 \mathrm{mg} / \mathrm{kg}$ corresponding to $20 \mathrm{mg}(\mathrm{Mg}) / \mathrm{kg}$ in the complex), Group 5. DL-pGlu acid (110 mg/ $\mathrm{kg}$ corresponding to $30 \mathrm{mg}(\mathrm{Mg}) / \mathrm{kg}$ in the complex), Group 6: $\left[\mathrm{Mg}(\mathrm{DL}-\mathrm{pGlu})_{2}\right](80 \mathrm{mg}, 20 \mathrm{mg}(\mathrm{Mg}) / \mathrm{kg})$ and Group 7: [Mg(DLpGlu $)_{2}$ ] (121 mg, $\left.30 \mathrm{mg}(\mathrm{Mg}) / \mathrm{kg}\right)$. Saline solution and compounds were administered orally by gavage ( $p o$ ) for 14 days.

\section{Forced swimming test (FST)}

FST employs forced swimming stimuli as stressor to generate a behavior characterized by increased immobility time [22]. Swimming sessions were conducted by placing rats in individual Plexiglas cylinders $(46 \mathrm{~cm}$ tall $\times 20 \mathrm{~cm}$ in diameter), filled with water $\left(23-25^{\circ} \mathrm{C}\right)$ up to $30 \mathrm{~cm}$ from bottom. All swimming sessions were carried out between 12:00 and 16:00 h and two sessions were conducted: an initial 15 min pre-test on day 1 followed by a 5 min test on day 15. Drug treatments began on day 1 after the pre-test session and it was administered from day 1 to 14 [22]. At the end of both swimming sessions, rats were removed from the cylinders, dried with towels, placed in heated cages for $15 \mathrm{~min}$, allowed to rest and recover, and then returned to their home cages. The cylinders were emptied and cleaned between rat tests. Each animal was assigned randomly to a treatment, and was only employed for one pre-test/test session. Data were analyzed with two-way ANOVA followed by Tukey's test for multiple comparisons.

\section{Behavioral scoring}

For behavioral sampling, rats were rated at $5 \mathrm{~s}$ intervals throughout the duration of the forced swimming session. At each $5 \mathrm{~s}$ interval, the predominant behavior was assigned to one of three categories: (1) immobility: floating in the water without struggling, and making only those movements necessary to keep the head above the water; (2) swimming: making active swimming motions, more than necessary to merely keep the head above water (i.e., moving around in the cylinder); and (3) climbing: making active movements with forepaws in and out of the water, usually directed against the walls. Scores for each behavior were expressed as total behavioral counts per 5-min session [22].

\section{Thermal stimulus-induced pain (analgesic activity-hot plate test)}

The hot plate consisted of an electrically heated surface (Socrel DS-35, Ugo Basile, Comerio, VA, Italy) kept at a constant temperature of $54 \pm 0.8^{\circ} \mathrm{C}$. The rats were kept inside a circular transparent plastic cage on the hot plate. The time taken for the rats to respond to the thermal stimulus (licking paws or jumping surface) was recorded as the response latency (in seconds). If the animals did not respond within $45 \mathrm{~s}$ (cut-off time), they were removed from the plate to avoid tissue damage [22]. Animals were distributed in 4 groups: Group 1: saline solution $(0.4 \% \mathrm{NaCl})$ (control), Group 2: DL-pGLu acid, Group 3: $\mathrm{MgCl}_{2}$ and Group 4: [Mg (DL-pGlu $)_{2}$ ]. The doses are the same as for the antidepressant effect. Saline solution and compounds were administered orally by gavage (po) for 14 days. The antinociceptive activity chronic administration (for 14 days), was evaluated using hot plate method. Statistical analysis was carried out by one-way ANOVA followed by Bonferroni's test.

\section{Open field test (OFT)}

The locomotor activity may influence immobility in the FST or in the latency response in the hot plate test [22]. To determine whether different treatments that were effective in both tests had non-specific effects, the OFT was performed.

The apparatus used consisted of a black, square open field $(60 \mathrm{~cm} \times 60 \mathrm{~cm})$ with the floor divided in squares $(15 \times 15 \mathrm{~cm})$ by means of white lines. The open field was placed in a quiet room only illuminated with a $75 \mathrm{~W}$ electric bulb hung $75 \mathrm{~cm}$ above it. Testing was performed between 14:00 and 17:00 h.

Each animal was placed in the center of the open-field arena and the locomotor activity was expressed as the number of floor units the animal entered with all of its limbs over a period of $5 \mathrm{~min}$ (ambulatory counts). After each animal was removed, the open field was carefully cleaned with a damp cloth.

Until day 14, these studies were conducted exactly as the FST or hot plate test studies; but instead of re-testing in the FST or testing in the hot plate test on day 14 , animals were subjected to an open field session. The behavior was scored by an observer who was unaware of the experimental procedures previously performed on the animals and the results were expressed as mean \pm SEM.

\section{Results}

The structure of $\left[\mathrm{Mg}(\mathrm{DL}-\mathrm{pGlu})_{2}\right]$ was characterized by single crystal X-ray analysis. Fig. 1 is an ORTEP [26] drawing of the salt (Tables S1-S7). There is in general agreement with the reported structure of free pyroglutamic acid [27] and the major difference arises as a consequence of deprotonation at the $-\mathrm{COOH}$ group. The $\mathrm{Mg}(\mathrm{II})$ ion is sited on a crystallographic two-fold axis in an octahedral environment, coordinated to the carboxylic oxygen atoms of six neighboring and symmetry-related ligands (Additional chemical information in supplementary material).

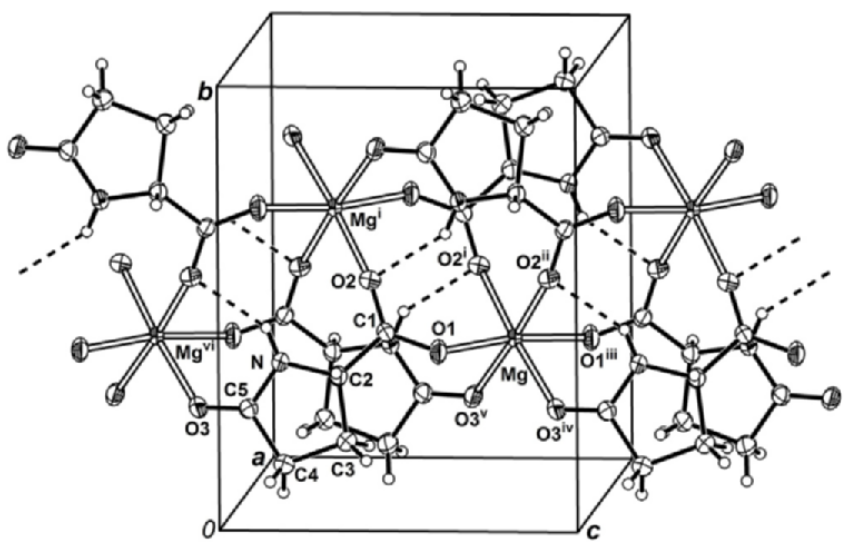

Fig. 1. View of $\left[\mathrm{Mg}(\mathrm{DL}-\mathrm{pGlu})_{2}\right]$ down the crystal $a$-axis showing the labeling of the non-H atoms and their displacement ellipsoids at the $50 \%$ probability level. Ligandmetal bonds are indicated by open lines and $\mathrm{H}$-bonds by dashed lines. 
In vitro determination of potential biological-pharmacological activities

\section{Anti-thyroid activity}

Based on the chemical possibilities of the ligand and the complex (presence of $\mathrm{NH}$ group), the ability to form charge transfer-iodine complex and to inhibit LPO have been evaluated $[19,23]$. Neither the ligand nor the $\left[\mathrm{Mg}(\mathrm{DL}-\mathrm{pGlu})_{2}\right]$ complex have absorption bands that masked the CT-complex band.

The ligand did no interact with iodine. A progressive increment of the $\left[\mathrm{Mg}(\mathrm{DL}-\mathrm{pGlu})_{2}\right]$ concentration produced an increment in the absorbance of the band at $363 \mathrm{~nm}$ (Fig. 2A) indicating complexation with molecular iodine. Applying the Lang's method to the experimental data (Fig. 2B), the formation constant $\mathrm{K}_{\mathrm{c}}=45366.5 \pm 29 \mathrm{M}^{-1}\left(\Delta \mathrm{G}^{0}=-26.55 \mathrm{KJ} / \mathrm{mol}\right)$ and the molar extinction coefficient of the CT complex $\varepsilon=2079.5 \pm 25 \mathrm{M}^{-1} \mathrm{~cm}^{-1}$ were determined.

Despite the anti-thyroid ability displayed by the complex, unfortunately both the complex and the ligand did not show inhibition of LPO.

In vivo assessment of potential pharmacological activities

\section{Antidepressant activity}

The antidepressant activity of DL-pyroglutamic acid and [Mg (DL-pGlu $)_{2}$ ] was evaluated using the FST [22]. $\mathrm{MgCl}_{2}$ was also tested to evaluate a synergistic potential behavior and to compare with previously reported data [25]. The effects of a chronic treatment with $\left[\mathrm{Mg}(\mathrm{DL}-\mathrm{pGlu})_{2}\right]$ on the total duration of immobility time in rats are shown in Fig. 3A. Contrasting with the control group (sal), $\mathrm{MgCl}_{2}$ (20 and $30 \mathrm{mg}(\mathrm{Mg}) / \mathrm{kg}$ ) and DL-pGlu acid (the equivalent quantity to 20 and $30 \mathrm{mg}(\mathrm{Mg}) / \mathrm{kg}$ ) in the complex) failed to affect the immobility time. Interestingly, at the higher tested dose of $\left[\mathrm{Mg}(\mathrm{DL}-\mathrm{pGlu})_{2}\right](30 \mathrm{mg}(\mathrm{Mg}) / \mathrm{kg})$ the immobility time decreased $(22 \%, p<0.05)$ and a significant increase in swimming time $(106 \%, p<0.05)$ were observed without affecting considerably the frequency of the climbing behavior in comparison with the control group (Fig. 3A, sal). At a low dose of the complex $(20 \mathrm{mg}(\mathrm{Mg}) / \mathrm{kg})$, it did not significantly change immobility time compared with the treatment of saline solution and $\mathrm{MgCl}_{2}(30 \mathrm{mg}$ $(\mathrm{Mg}) / \mathrm{kg})$. Additionally, the effect of [Mg(DL-pGlu $\left.)_{2}\right](20$ and $30 \mathrm{mg}$ $(\mathrm{Mg}) / \mathrm{kg}$ ) on spontaneous locomotor activity was evaluated. Fig. 3B includes the effects of $\mathrm{MgCl}_{2}$ (20 and $30 \mathrm{mg}(\mathrm{Mg}) / \mathrm{kg}$ ) and DL-pGlu acid (the equivalent quantity to 20 and $30 \mathrm{mg}(\mathrm{Mg}) / \mathrm{kg}$ in the complex) for the sake of comparisons. Compared with the control group, none of these treatments affected the activity levels when rats were tested in an open field chamber instead of the forced swimming cylinders during the re-test (Fig. 3B). Similarly, the body weight of the rats was no affected after the treatments (Fig. S8).

\section{Thermal stimulus-induced pain (hot plate test)}

The antinociceptive activity of the compounds was determined. It has to be considered that an increase in reaction time (latency, sec) compared to basal (saline solution) is proportional to analgesic activity of the tested compounds. It can be appreciated (Fig. 4) that $\mathrm{MgCl}_{2}$ (20 and $30 \mathrm{mg}(\mathrm{Mg}) / \mathrm{kg}$ ) and DL-pGlu acid (the equivalent quantity to 20 and $30 \mathrm{mg}(\mathrm{Mg}) / \mathrm{kg}$ in the complex) treatments failed to alter the reaction time significantly while the treatment with $\left[\mathrm{Mg}(\mathrm{DL}-\mathrm{pGlu})_{2}\right](30 \mathrm{mg}(\mathrm{Mg}) / \mathrm{kg})$ had a greater antinociceptive effect (increment of 70\%, $p<0.05$ ) compared with the control group (Fig. 4, sal).

\section{D fluorescence spectroscopy}

Fig. 5 presents the 3D fluorescence spectra of BSA in the absence and presence of DL-pGlu acid and $\left[\mathrm{Mg}(\mathrm{DL}-\mathrm{pGlu})_{2}\right]$ complex, respectively. It is shown that Peak $A$, associated with the Trp and Tyr residues (Fig. 5, Table 1) slightly increases its intensity for the magnesium complex and in opposition in the ligand slightly decreases in comparison with BSA. On the contrary, Peak B, associated with the polypeptide backbone decreases its intensity for the metal complex and increases for the ligand.

\section{Discussion}

In the present study a crystal of a new coordination complex, $\left[\mathrm{Mg}(\mathrm{DL}-\mathrm{pGlu})_{2}\right]$, was obtained (Fig. 1) in contrast to the $\mathrm{Mg}(\mathrm{II})-$ pyroglutamate salt (magnesium pidolate) whose crystalline structure is unknown [25]. This compound has similar octahedral environment than calcium pyroglutamate [28], same structure in the polycrystalline material and in solution in opposition to other magnesium compounds (magnesium gluconate) [29]. For this compound, antithyroid, antidepressant and antinociceptive activities were evaluated.

It is known that the overproduction of L-tri-iodothyronine $\left(\mathrm{T}_{3}\right)$ and thyroxine $\left(\mathrm{T}_{4}\right)$ leads to hyperthyroidism and that specific inhibitors control them by blocking the thyroid hormone
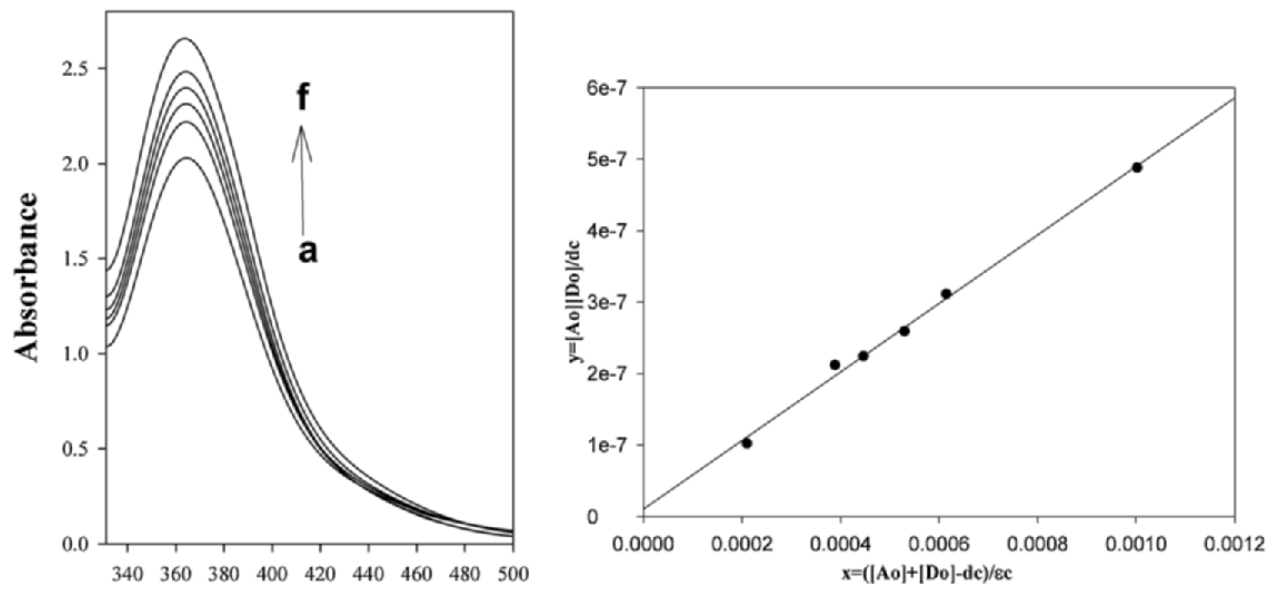

wavelength (nm)

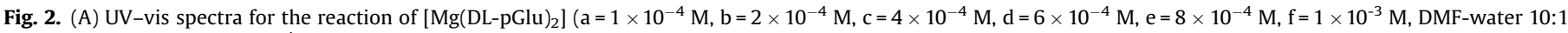
solutions) with iodine $\left(2 \times 10^{-4} \mathrm{M}\right.$, ethanol $)$ at $298 \mathrm{~K}, 1 \mathrm{~cm}$ of optical path length. (B) Lang s method. 

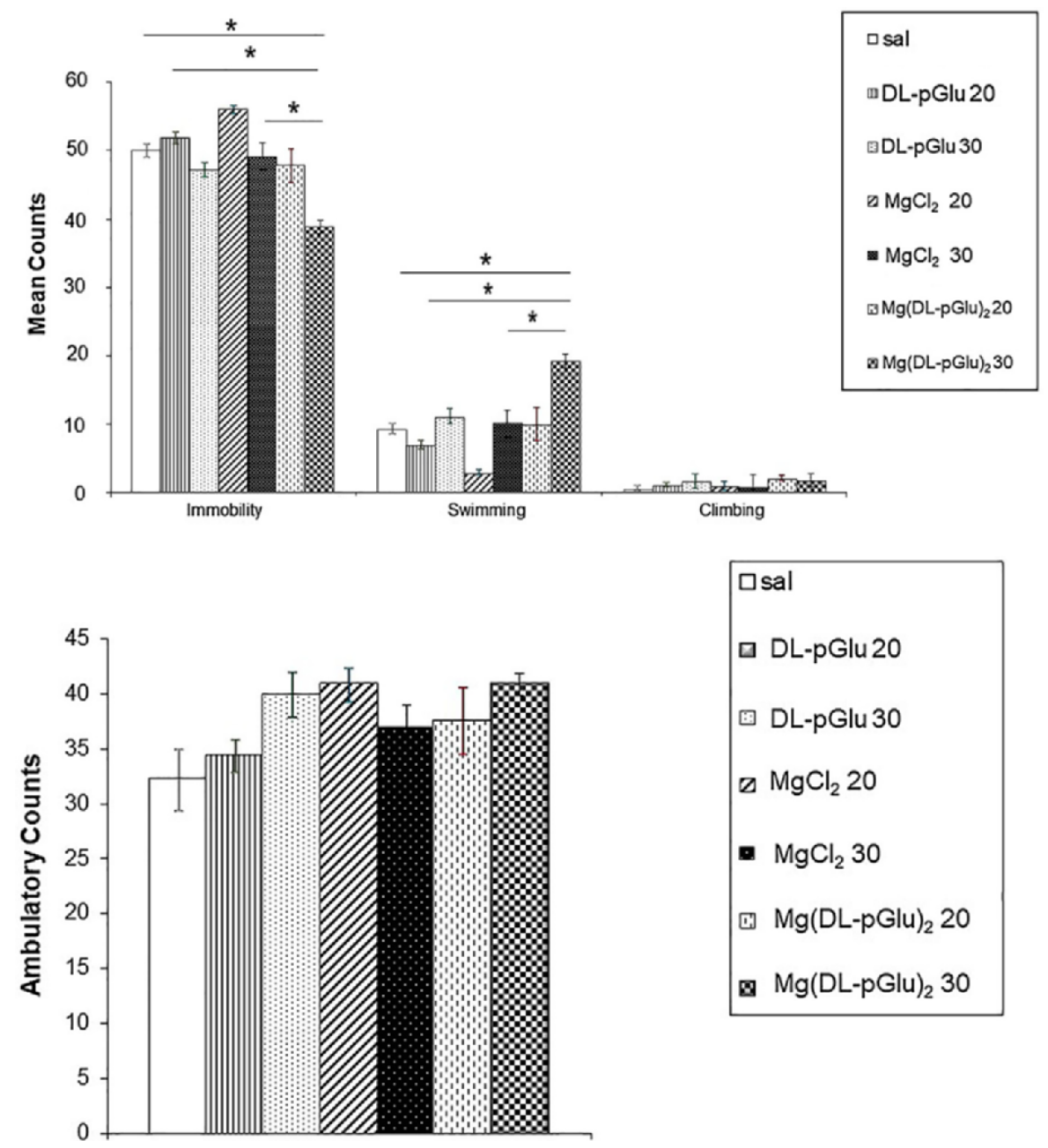

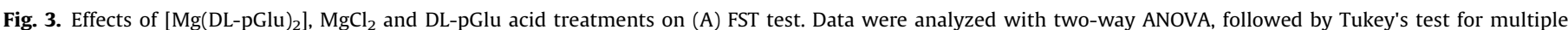

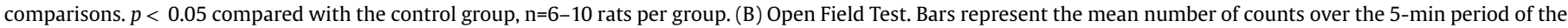
test $( \pm$ SEM). Results are expressed as mean \pm SEM, $n=5-10$ rats per group.

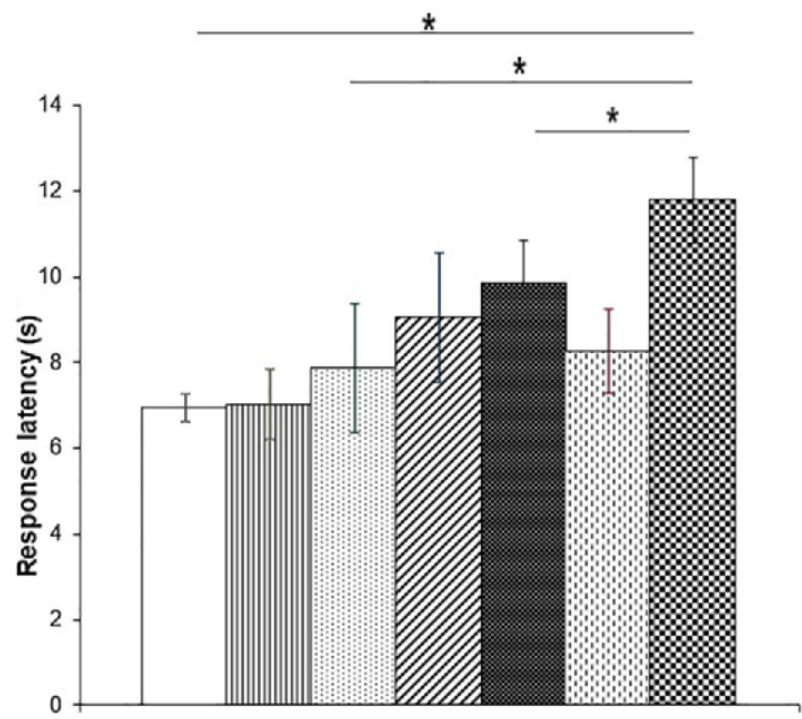

\begin{tabular}{|c|c|}
\hline \multicolumn{2}{|c|}{ 口sal } \\
\hline 四 & DL-pGlu 20 \\
\hline 国 & DL-pGlu 30 \\
\hline 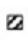 & $\mathrm{MgCl}_{2} 20$ \\
\hline & $\mathrm{MgCl}_{2} 30$ \\
\hline 回 & $\mathrm{Mg}(\mathrm{DL}-\mathrm{pGlu})_{2} 20$ \\
\hline & $\mathrm{Mg}(\mathrm{DL}-\mathrm{pGlu})_{2} 30$ \\
\hline
\end{tabular}

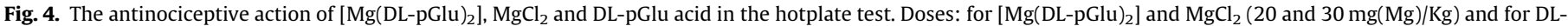

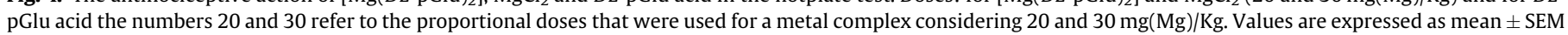
for 6-10 rats per group. ${ }^{*} p<0.05$, compared with the control group. Data were analyzed with one-way ANOVA and followed Bonferroni's test. 

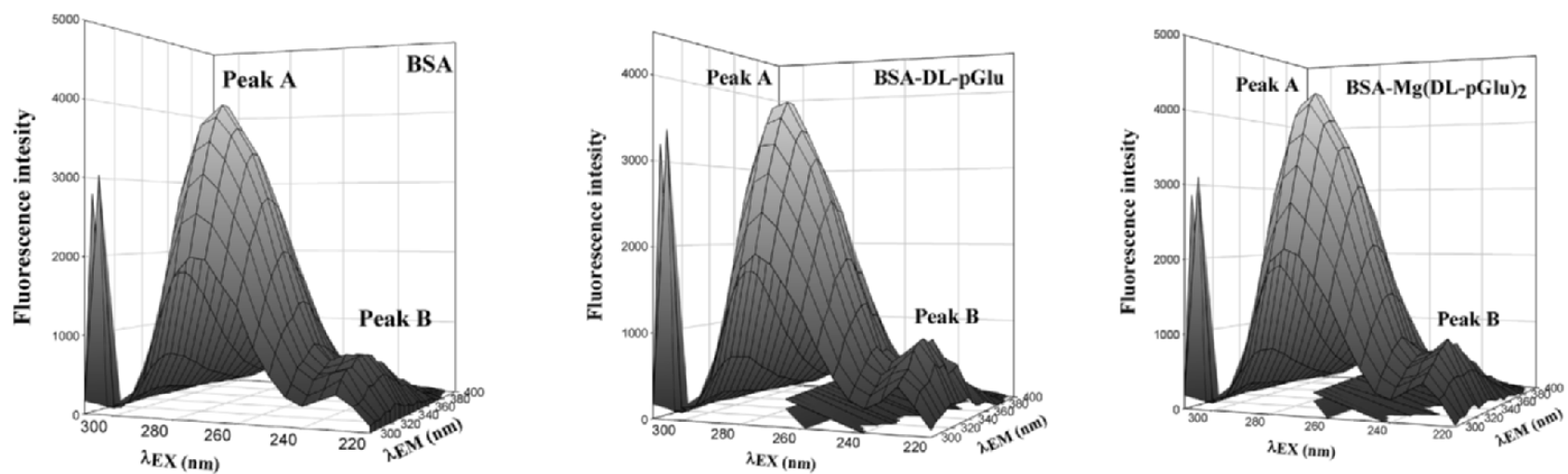

Fig. 5. Three-dimensional fluorescence spectra of $6 \mu \mathrm{MBSA}, 6 \mu \mathrm{M}$ BSA-500 $\mu \mathrm{M}$ DL-pGlu acid and $6 \mu \mathrm{M}$ BSA-500 $\mu \mathrm{M}\left[\mathrm{Mg}(\mathrm{DL}-\mathrm{pGlu})_{2}\right.$ ].

Table 1

3D Fluorescence Spectral Parameters.

\begin{tabular}{lllll}
\hline & Peak position & $\lambda$ ex/ $/$ em $(\mathrm{nm} / \mathrm{nm})$ & $\Delta \lambda$ & Intensity \\
\hline BSA & A & $280 / 337.9$ & 57.9 & 4043.5 \\
& B & $230 / 340.3$ & 110.3 & 577.6 \\
BSA-DL-pGlu acid & A & $280 / 335.5$ & 55.5 & 3814.3 \\
& B & $230 / 339.0$ & 109 & 673.1 \\
BSA-[Mg(DL-pGlu $\left.)_{2}\right]$ & A & $280 / 337.3$ & 57.3 & 4215.3 \\
& B & $230 / 334.4$ & 54.4 & 559.3 \\
\hline
\end{tabular}

biosynthesis or reducing the conversion of $\mathrm{T}_{4}$ to $\mathrm{T}_{3}[22]$. Antidepressants may act also as antithyroid drugs because of their ability to form charge-transfer complexes with iodine [19] and to block in vivo the iodination of the TPO enzyme. The inactivation may occur through the formation of hydrogen bonding between the distal histidine group (NH group) of the molecule and the active center of the enzyme [30]. Using $K_{c}$ constant as a criterion for evaluation of potential antithyroid activity [19], the compound $\left(K_{c}>100 M^{-1}\right.$, negative $\Delta G^{0}$ value $)$ can be considered a potential antithyroid agent in a spontaneous process. The presence of non-coordinated $\mathrm{NH}$ groups could be the reason for the revealed activity. Nevertheless a direct comparison with other molecules could not be performed; $\mathrm{K}_{\mathrm{c}}$ constant is in the same order of magnitude of methimazole [31]. The ligand was not able to interact with iodine and the enzyme inhibition experiments suggest that neither the ligand nor the complex were able to inhibit LPO.

The antidepressant in vivo experiments were performed on Wistar rats (Fig. 3A). In the last years, the antidepressant effects exerted by $\mathrm{Mg}$ (II) ions were determined. Poleszak et al. [25] using magnesium chloride, sulfate and hydroaspartate (acute and chronic experiments, 20 and $30 \mathrm{mg}(\mathrm{Mg}) / \mathrm{Kg}$, intraperitoneally (ip) administration) on albino Swiss mice observed almost a 20$30 \%$ reduction on the immobility behavior. Similar results were obtained by Decollogne et al. [32] on OF1 mice (acute treatment, ip administration and $30 \mathrm{mg}(\mathrm{Mg}) / \mathrm{Kg}$ doses). Other tests were performed on the basis of magnesium depletion [33] on mice (C57BL/6 J mice, 4 weeks) and humans [34] or by joint administration of $\mathrm{Mg}(\mathrm{II})$ with typical antidepressants [35,36]. Poleszak et al. performed experiments on male Wistar rats and demonstrated the influence of magnesium on the lowering of the immobility time [37]. In our experiments, Wistar rats were used and the compounds were given orally because of their high solubility in water. Yamamoto et al. [38] studied the antidepressant effect of pyroglutamyl peptides in mice and in this context determined the activity of pyroglutamic acid $(10 \mathrm{mg} / \mathrm{Kg}$, ip) which resulted ineffective. In a previous report [25], the $\mathrm{Mg}$ (II)pyroglutamate salt ( $\mathrm{Mg}(\mathrm{II})$ content $8 \%$, magnesium pidolate) is mentioned but it was not used for the measurement of the antidepressant effect. Thus, for a first time, a magnesium complex was proved to act as antidepressant.

FST experiments revealed that the effective dose of the complex was the higher tested concentration $(30 \mathrm{mg}(\mathrm{Mg}) / \mathrm{Kg}$, Fig. $3 \mathrm{~A})$ in which the complex produced one of the most important decrease in the immobility time (22\%) and increment in swimming behavior (106\%). This effect resulted effective contrary to the lower tested dose $(20 \mathrm{mg}(\mathrm{Mg}) / \mathrm{kg})$. Because of the inactivity of the ligand and $\mathrm{MgCl}_{2}$ in their individual determinations (Fig. 3A), the observed effect can be entirely attributed to the presence of the magnesium complex and therefore a synergistic effect can be discarded. Data concerning to antidepressant activity of magnesium complexes are scarce. $\mathrm{Mg}$ (II)-hydroaspartate salt resulted effective at $30 \mathrm{mg}$ $(\mathrm{Mg}) / \mathrm{kg}(\mathrm{ip})$ on albino Swiss mice but a direct comparison with this data cannot be performed.

Locomotor activity test (Fig. 3B) showed that the FST test did not affect the activity levels supporting the fact that the immobility changes can be exclusively attributed to the effect produced by the new compound. Finally, experiments controlling the body weight of the rats showed that the treatments did not induced changes in weight compared to the control. Thus, this compound can be proposed as a potential antidepressant agent without affecting locomotor activity and body weight in contrast to other antidepressants [39].

Several pre-clinical studies revealed antinociceptive properties of some magnesium compounds. Administration of the $\mathrm{MgCl}_{2}$ before arthritis induction prevented carrageenan-induced hypernociception [40]. It was also proved in patients suffering osteoarthritis [41] or undergoing arthroscopic knee surgery. Close to the coordination complex $\left[\mathrm{Mg}(\mathrm{DL}-\mathrm{pGlu})_{2}\right.$ ], magnesium-pidolate (oral administration) was able to reduce the occurrence of painful days in patients with sickle cell disease [42].

The results of this study show that the $\left[\mathrm{Mg}(\mathrm{DL}-\mathrm{pGlu})_{2}\right]$ complex (30 $\mathrm{mg}(\mathrm{Mg}) / \mathrm{Kg}$ ) had a significant antinociceptive effect $(70.0 \%)$ after chronic administration when compared with the control. In addition, the increased response to thermal nociception through this treatment can be considered specific since it is not attributable to changes in locomotor activity.

The in vivo experiments let us propose a dual action of the magnesium complex as a potential antidepressant and analgesic agent.

The investigation of the binding between drugs and serum albumin is relevant in pharmacology and pharmacodynamic fields. 
3D fluorescence spectroscopy is used to study the conformational changes of BSA after the interaction with the compound of interest. Quenching is typically expected but sometimes the enhancement of the fluorescence intensity occurs associated to a possible intercalation process [43]. BSA 3D spectrum presents: Peak A (Trp and Tyr residues, Fig. 5) which reflects the polarity of the microenvironment and Peak B (polypeptide backbone structures) associated to exposition of hydrophobic regions [44]. Different kinds of interactions were produced by the ligand and the complex. Peak A slightly increases its intensity for the magnesium complex and in opposition the interaction with the ligand slightly decreases its intensity in comparison with BSA. On the contrary, Peak B decreases its intensity for the metal complex and increases for the ligand. These differences may arise from the total charge. The ligand, at physiological $\mathrm{pH}$ is probably deprotonated $\left(-\mathrm{COO}^{-}\right)$and electrostatic interactions were involved. Neutral complex possible preferred covalent type of interaction through the free $\mathrm{NH}$ groups in the molecule.

\section{Conclusions}

In the last years magnesium has spurred much interest to elucidate its participation in depression and pain. In this work we demonstrated that the presence of the racemic DLPyroglutamic acid favors crystallization of [Mg(DL-pGlu $\left.)_{2}\right]$ complex. We obtained promising results (i) antidepressant effects, regarding the lowering of the immobility time (22\%) and the increment of the swimming ability (106\%) with a $30 \mathrm{mg}$ $(\mathrm{Mg}) / \mathrm{kg}$ dose; (ii) analgesic activity by increasing the response latency in $70.0 \%$ and (iii) anti-thyroid activity assayed in the ability of the complex to capture iodine $\left(K_{c}>100\right)$. By 3D fluorescence spectroscopy, the interaction with the carrier protein albumin was also ascertained.

\section{Conflict of interest}

The authors declare that they have no conflict of interest.

\section{Acknowledgments}

This work was supported by CONICET (Grants PIP 0611 and PIP 0651), ANPCyT (Grant PICT16-1814), UNLP (Grants 11/X777 and 11/ X709) of Argentina. LGN, EGF, GAE and OEP are Research Fellows of CONICET. JEP and PAMW are Research Fellows of CICPBA, Argentina.

\section{Appendix A. Supplementary data}

Supplementary material related to this article can be found, in the online version, at doi:https://doi.org/10.1016/j.pharep.2019.07.009.

\section{References}

[1] N-EL Saris, Mervaala E, Karppanen H, Khawaja JA. Lewenstam A. Magnesium. An update on physiological, clinical and analytical aspects. Clin Chim Acta 2000;294:1-26.

[2] Vormann J. Magnesium: nutrition and metabolism. Mol Asp Med 2003;24:27-37.

[3] Sheth PB, Dechow FJ. Oral magnesium and potassium compositions and use. 1990 US 4954349.

[4] Bibbiano FA, Abano Terme DM, Selvazzano JCS. Composition for the relief of heat stress. 2006 US007001612B2.

[5] Liu G, Mao F. Magnesium compositions and use thereof. 2008 US0248100A1.

[6] Liu G, Meister BK, Zhou H, Mao F. Magnesium compositions and use thereof. 2008 W0116226A2.

[7] Singh CU. Novel pharmaceutical compositions for treating chronic pain and pain associated with neuropathy. 2013 US0189354A1.

[8] Galey JB. Metal complexes for promoting skin desquamation and/or stimulating epidermal renewal. 2003 US20030224028A1.

[9] Couzinier J-P, Cousse H. Composition pharmaceutique effervescente à base de magnesium. 1983 FR2546064A1.
[10] Krimmer H-P, Drauz K, Werner S. Methods of preparing alkaline earth metal salts of 2-pyrrolidone-5-carboxylic acid. 1990 US4921971.

[11] Laden K, Spitzer R. Identification of a natural moisturizing agent in skin. J Soc Cosmet Chem 1967:18:351-60.

[12] http://www.who.int/en/news-room/fact-sheets/detail/depression.

[13] Młyniec K, Davies CL, Gómez de Agüero Sánchez I, Pytka K, Budziszewska B, Nowak G. Essential elements in depression and anxiety. Part I. Pharmacol Rep 2014;66:534-44.

[14] Serefko A, Szopa A, Wlaź P, Nowak G, Radziwoń-Zaleska M, Skalski M. Poleszak e magnesium in depression. Pharmacol Rep 2013;65:547-54.

[15] Eby GA, Eby KL. Magnesium for treatment-resistant depression: a review and hypothesis. Med Hypotheses 2010;74:649-60.

[16] Fukao A, Takamatsu J, Murakami Y, Sakane S, Miyauchi A, Kuma K, et al. The relationship of psychological factors to the prognosis of hyperthyroidism in antithyroid drug-treated patients with Graves' disease. Clin Endocrinol 2003;58:550-5.

[17] Joffe RT, Levitt AJ, Young LT. The thyroid, depression magnesium and calcium in major. Biol Psychiatry 1996;40:428-9.

[18] Jones JE, Desper PC, Shane SR, Flink EB. Magnesium metabolism in hyperthyroidism and hypothyroidism. J Clin Invest 1966;45:891-900.

[19] Rousseau A, Comby F, Buxeraud J, Raby C. Spectroscopy analysis of charge transfer complex formation and peroxidase inhibition with tricyclic antidepressant drugs: potential anti-thyroid action. Biol Pharm Bull 1996;19:726-8.

[20] Salem H. Spectrophotometric determination of adrenergic blocking agents in pharmaceutical formulations. J Pharm Biom Anal 2002;29:527-38.

[21] Kratz F, Elsadek B. Clinical impact of serum proteins on drug delivery. J Control Release 2012;161:429-45.

[22] Martini N, Parente JE, Toledo ME, Escudero GE, Laino CH, Martínez Medina JJ, et al. Evidence of promising biological-pharmacological activities of the sertraline-based copper complex: $\left(\mathrm{SerH}_{2}\right)_{2}\left[\mathrm{CuCl}_{4}\right]$. J Inorg Biochem 2017:174:76-89.

[23] Escudero GE, Ferraresi Curotto V, Laino CH, Pis Diez R, Williams PAM, Ferrer EG. Sertraline and its iodine product: experimental and theoretical vibrational studies. Spectrochim Acta Part A: Mol Biomol Spectrosc 2013;104:271-9.

[24] Roy G, Jayaram PN, Mugesh G. Inhibition of lactoperoxidase-catalyzed oxidation by imidazole-based thiones and selones: a mechanistic study. Chem Asian J 2013;8:1910-21.

[25] Poleszak E, Szewczyk B, Kedzierska E, Wlaźc P, Pilc A, Nowak G. Antidepressant- and anxiolytic-like activity of magnesium in mice. Pharmacol Biochem Behav 2004;78:7-12.

[26] Farrugia LJ. ORTEP-3 for Windows - a version of ORTEP-III with a Graphical User Interface (GUI). J Appl Cryst 1997;30:65-566.

[27] Panda MK, Runcevski T, Husain A, Dinnebier RE. Naumov P. perpetually selfpropelling chiral single crystals. J Am Chem Soc 2015;137:1895-902 Code: PYRGLU11; P2 $2 / c$.

[28] Schmidbaur H, Kiprof P, Kumberger O, Riede J. Metal bonding by amino acids: preparation and crystal structures of calcium Bis-L-pyroglutamate and Lithium l-pyroglutamate. J Chem Ber 1991;124:1083-7.

[29] Trivedi MK, Dixit N, Panda P, Sethi KK, Jana S. In-depth investigation on physicochemical and thermal properties of magnesium (II) gluconate using spectroscopic and thermoanalytical techniques. J Pharm Anal 2017;7:332-7.

[30] Salem H. Spectrophotometric determination of adrenergic blocking agents in pharmaceutical formulations. J Pharm Biom Anal 2002;29:527-38.

[31] Urquiza NM, Islas MS, Ariza ST, Jori N, Martinez Medina JJ, Lavecchia MJ, et al. Anti-thyroid and antifungal activities, BSA interaction and acid phosphatase inhibition of methimazole copper(II) complexes. Chem-Biol Interact 2015:229:64-72.

[32] Decollogne S, Tomas A, Lecerf C, Adamowicz E, Seman M. NMDA receptor complex blockade by oral administration of magnesium: comparison with MK-801. Pharmacol Biochem Behav 1997;58:261-8.

[33] Singewald N, Sinner C, Hetzenauer A, Sartori SB, Murck H. Magnesiumdeficient diet alters depression- and anxiety-related behavior in miceinfluence of desipramine and Hypericum perforatum extract. Neuropharm 2004;47:1189-97.

[34] Eby GA, Eby KL. Rapid recovery from major depression using magnesium treatment. Med Hypotheses 2006;67:362-70.

[35] Poleszak E, Wlaź P, Szewczyk B, Kedzierska E, Wyska E, Librowski T, et al. Enhancement of antidepressant-like activity by joint administration of imipramine and magnesium in the forced swim test: behavioral and pharmacokinetic studies in mice. Pharmacol Biochem Behav 2005:81:524-9.

[36] Poleszak E, Wlaź P, Kedzierska E, Nieoczym D, Wyska E, Szymura-Oleksiak J, et al. Immobility stress induces depression like behavior in the forced swim test in mice. Effect of magnesium and imipramine. Pharmacol Rep 2006;58:746-52.

[37] Poleszak E, Wlaź P, Kedzierska E, Radziwon-Zaleska M, Pilc A, Fidecka S, et al. Effects of acute and chronic treatment with magnesium in the forced swim test in rats. Pharmacol Rep 2005;57:654-8.

[38] Yamamoto Y, Mizushige T, Mori Y, Shimmur Y, Fukutomi R, Kanamoto R, et al. Antidepressant-like effect of food-derived pyroglutamyl peptides in mice. Neuropeptides 2015;51:25-9.

[39] Ranjbar S, Pai NB, Deng C. The association of antidepressant medication and body weight gain. Online J Health Allied Sci 2013;12:1-9. 
[40] De Franceschi L, Bachir D, Galacteros F, Tchernia G, Cynober T, Neuberg D, et al. Oral magnesium pidolate: effects of long-term administration in patients with sickle cell disease. Br J Haem 2000;108:284-9.

[41] Fioravanti A, Tenti S, Giannitti C, Fortunati NA, Galeazzi M. Short- and longterm effects of mud-bath treatment on hand osteoarthritis: a randomized clinical trial. Int J Biometeorol 2014;58:79-86.

[42] Bondok RS, Abd El-Hady AM. Intra-articularmagnesiumis effective for postoperative analgesia in arthroscopic knee surgery. Br J Anaesth 2006;97:389-92.
[43] Mandegani Z, Asadi Z, Asadi M, Karbalaei-Heidari HR, Rastegari B. Synthesis, characterization, DNA binding, cleavage activity, cytotoxicity and molecular docking of new nano water-soluble $\left[\mathrm{M}\left(5-\mathrm{CH}_{2} \mathrm{PPh}_{3}-3,4-\right.\right.$ salpyr $\left.)\right]\left(\mathrm{ClO}_{4}\right)_{2}(\mathrm{M}=\mathrm{Ni}$, Zn) complexes. Dalton Trans 2016;45:6592-611.

[44] Wang Y, Wang X, Wang J, Zhao Y, He W, Guo Z. Noncovalent interactions between a trinuclear monofunctional platinum complex and human serum albumin. Inorg Chem 2011;50:12661-8. 